\title{
No Tumor-Free Waiting Period after Treatment of Multilocular Cystic Renal Cell Carcinoma: A New Case and Review of the Literature
}

\author{
Ekamol Tantisattamo $^{a}$ April Elam $^{c}$ Jason Cobb ${ }^{a}$ Carla L. Ellis ${ }^{b}$ \\ James L. Bailey ${ }^{\mathrm{a}}$ \\ ${ }^{a}$ Renal Division, Department of Medicine, and ${ }^{b}$ Department of Pathology and Laboratory Medicine, Emory \\ University School of Medicine, and ' $D$ Department of Medicine, Morehouse School of Medicine, Atlanta, Ga., USA
}

\section{Key Words}

Kidney transplant · Multilocular cystic renal cell carcinoma .

Renal cell carcinoma - Tumor-free waiting period

\begin{abstract}
Most pretransplant malignancies require a tumor-free waiting period before transplantation. End-stage renal disease (ESRD) patients have an increased risk of renal cell carcinoma (RCC), which is mostly detected from routine screening during pre-kidney transplant evaluation. RCC must be quiescent prior to kidney transplantation. However, the tumor-free waiting period for RCC varies depending on the types of RCC. Multilocular cystic RCC (MCRCC), one subtype of clear cell $\mathrm{RCC}$, has low malignant potential and may not require a tumor-free waiting period. We report a case of an ESRD patient with a newly diagnosed MCRCC that was found during routine pre-kidney transplant evaluation. A plan for kidney transplantation within 6 months of successful tumor removal by nephrectomy was made. The literature regarding MCRCC in kidney transplantation is reviewed.
\end{abstract}

(c) 2014 S. Karger AG, Basel

\section{KARGER}

(c) 2014 S. Karger AG, Base

0250-8095/14/0402-0151\$39.50/0

E-Mail karger@karger.com

www.karger.com/ajn

\section{Introduction}

Kidney transplantation is the treatment of choice for end-stage renal disease (ESRD) [1]. It requires extensive pretransplant evaluation, and often is deferred for many reasons. Malignancy, both known and newly diagnosed, is one of the most common causes of a delay in transplantation. Renal cell carcinoma (RCC) is more prevalent in ESRD patients and needs to be under control before kidney transplantation can be considered [2]. However, multilocular cystic RCC (MCRCC) is one subtype of RCC with low malignant potential and may require no tumorfree waiting period. We report a case of newly diagnosed MCRCC that was found incidentally during pre-kidney transplant evaluation and review the literature about MCRCC in this setting.

\section{Case Report}

A 50-year-old African American man with a history of ESRD secondary to focal segmental glomerulosclerosis (FSGS) presented for a renal transplant evaluation. He had been well until 1.5 years earlier, when he presented with flu-like symptoms and acute shortness of breath. His serum creatinine was elevated at $18 \mathrm{mg} / \mathrm{dl} ; 2$ 


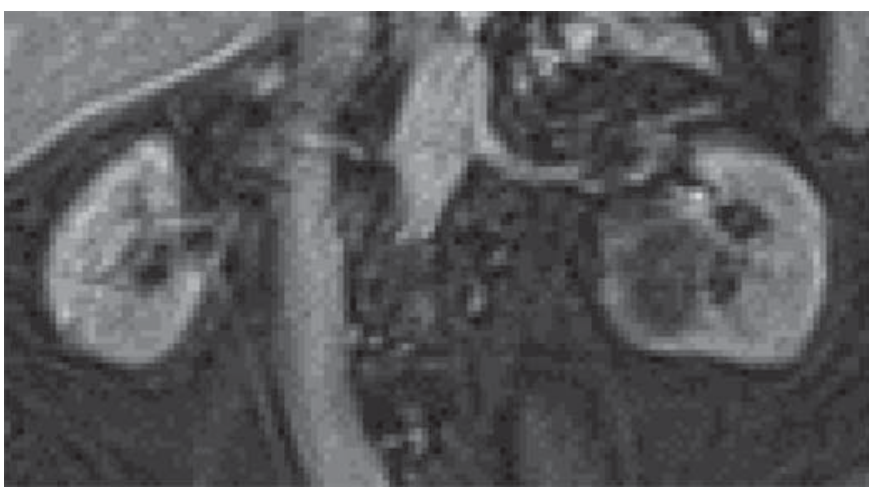

Fig. 1. Abdominal MRI (coronal view) with intravenous contrast revealed a $3.8 \times 4.4 \times 4.7 \mathrm{~cm}$ cystic lesion in the interpolar left kidney with a thick irregular septation and mild mural nodularity along the medial aspect of the lesion. There was no soft tissue enhancement within the lesion. No mesenteric or retroperitoneal lymphadenopathy was observed.

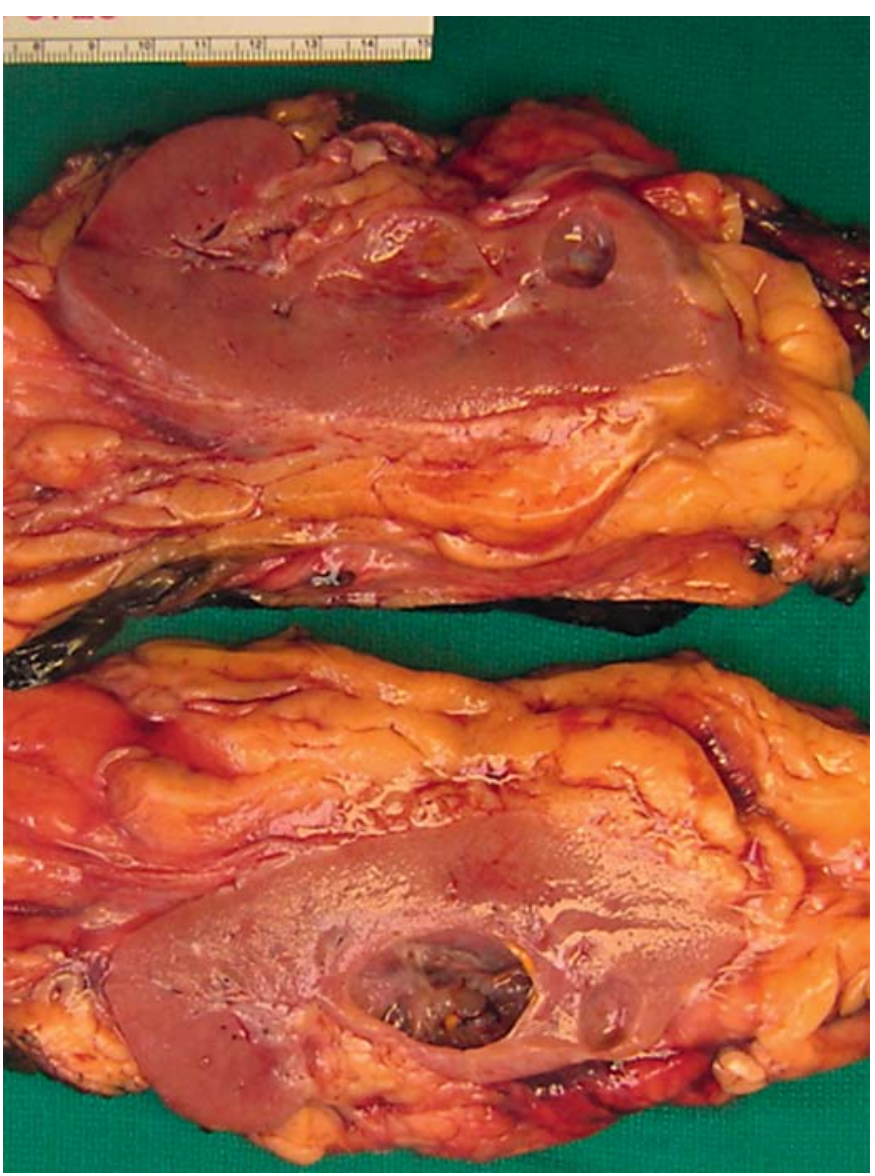

Fig. 2. Gross image shows the central cystic lesion with a multiloculated appearance of the smaller internal cysts. Note the associated thinned renal parenchyma with an inconspicuous corticomedullary junction consistent with ESRD. months earlier it was normal. Following emergent hemodialysis, a renal biopsy was performed and revealed collapsing FSGS in the setting of stage 3-4 membranous glomerulonephritis. There was moderate tubulointerstitial scarring with foci of microcystic tubular dilatation and superimposed diffuse, severe acute tubular injury. After 7 months, dialysis was discontinued. However, 8 months later, hemodialysis had to be reinitiated following a further decline in renal function. At the time of his transplant evaluation, he still made urine and a urinalysis revealed $600 \mathrm{mg} / \mathrm{dl}$ of protein. Hemoglobin was $14.3 \mathrm{~g} / \mathrm{dl}$. On examination, he was obese despite an intentional weight loss of $70 \mathrm{lbs}$ in 1.5 years. Abdominal and pelvic computerized tomography (CT) scan showed a $4.2 \times 4.1 \times$ $4.2 \mathrm{~cm}$ rounded contour asymmetric lesion involving the inferior pole of the left kidney which was concerning for a solid renal mass. Abdominal magnetic resonance imaging (MRI) was performed for better detail and revealed a $3.8 \times 4.4 \times 4.7 \mathrm{~cm}$ cystic lesion in the interpolar left kidney with a thickened septation and mild mural nodularity along the medical aspect of the lesion, without any definite enhancing soft tissue elements (fig. 1). As CT scan without contrast revealed a solid renal mass, the Bosniak classification, which is used for the determination of the possibility of malignancy in renal cystic lesions, could not be utilized in this case. However, by using MRI with contrast which showed a renal cyst, this lesion was classified as a category III cystic renal lesion by the Bosniak classification. Because of concern for renal cancer, he underwent left laparoscopic radical nephrectomy. Pathology revealed a $3.0 \times 2.3 \times 2.2 \mathrm{~cm}$ MCRCC, clear cell type, Fuhrman nuclear grade 1, T1A NX with negative surgical margins (fig. 2-4). He returned for 6-month follow-up and was deemed eligible to be listed as a kidney transplant candidate after repeated imaging showed no evidence of recurrence or metastatic disease.

\section{Discussion}

With improvement in short-term renal graft survival, long-term complications increase. Although cardiovascular disease is the most common complication in the post-kidney transplant period, malignancy still remains a major cause of morbidity and mortality and often leads to death with a functioning graft [3]. ESRD patients have an increased risk of cancer in the kidney-ureter-bladder system. Cancer of the kidneys has an incidence rate ranging from 3.3 to $9.9 \%$ depending on age and causes of renal failure [2]. Although RCC in ESRD patients tend to have more favorable pathologic features and outcomes [4], immunosuppressive medications after transplantation increase the risk of tumor growth, and there is a higher incidence of certain malignancies in ESRD patients. Therefore, most pretransplant malignancies are a contraindication for kidney transplantation, and pretransplant screening for malignancy is mandatory.

At one institution where an ipsilateral native nephrectomy was done at the time of renal transplantation, $4.3 \%$ of ESRD patients had RCC [5]. One prospective study 


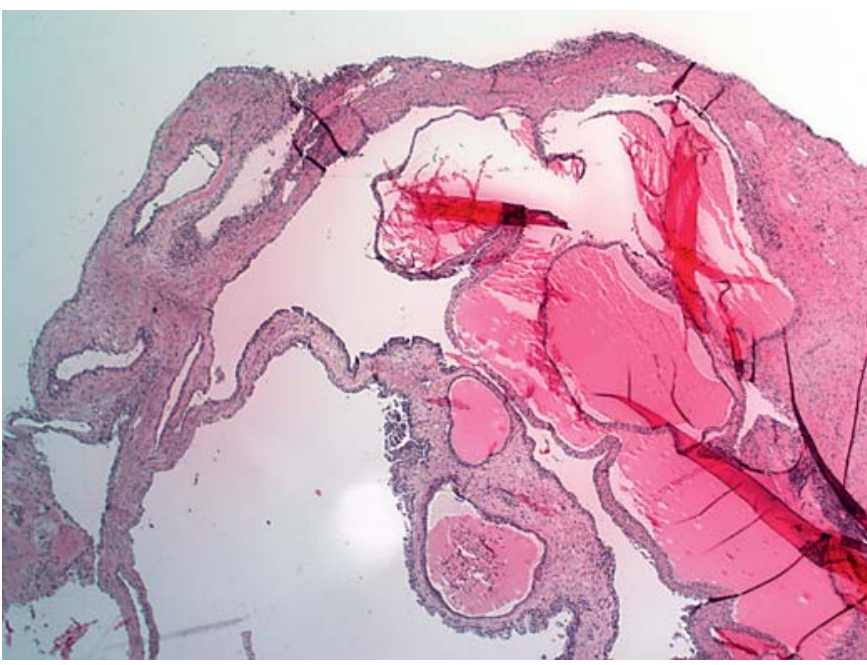

Fig. 3. Low-power HE-stained image showing the multiloculated morphology of the cystic lesion. Some larger cysts are filled with proteinaceous material, which causes prominent folding upon histologic processing.

demonstrated that the prevalence of RCC from screening renal ultrasound during pre-kidney transplant evaluation was up to $3.4 \%$ with the positive predictive value of a solid lesion on ultrasound of $100 \%$ [6]. In one series, the most common histopathology of these tumors was acquired cystic kidney disease-associated RCC followed by clear cell RCC and papillary RCC [7]. The 2001 American Society of Transplantation guidelines suggest that highrisk patients for RCC should be screened with both radiographic imaging and urine cytology [8]. Three common imaging modalities include ultrasound, CT scan, and MRI. Ultrasound is a noninvasive tool and is routinely used in pre-kidney transplant evaluation, but it is operator dependent and is not sensitive enough to detect renal cysts of $<5 \mathrm{~mm}$ [9]. To differentiate malignant from benign solid renal masses, tumor enhancement is the most important criterion, and abdominal CT scan with intravenous contrast is required [10]. In addition, CT scan is better than ultrasound in the detection of complex cysts [11], and the Bosniak classification of renal cysts can further assist the workup and management [12]. MRI is more sensitive in detecting renal lesions than ultrasound and provides further information regarding renal mass, local growth, and vena cava involvement. It is also used in patients who are allergic to contrast or are pregnant [13].

RCC is classified by morphologic, immunohistochemical, and molecular features into more than 40 subtypes.

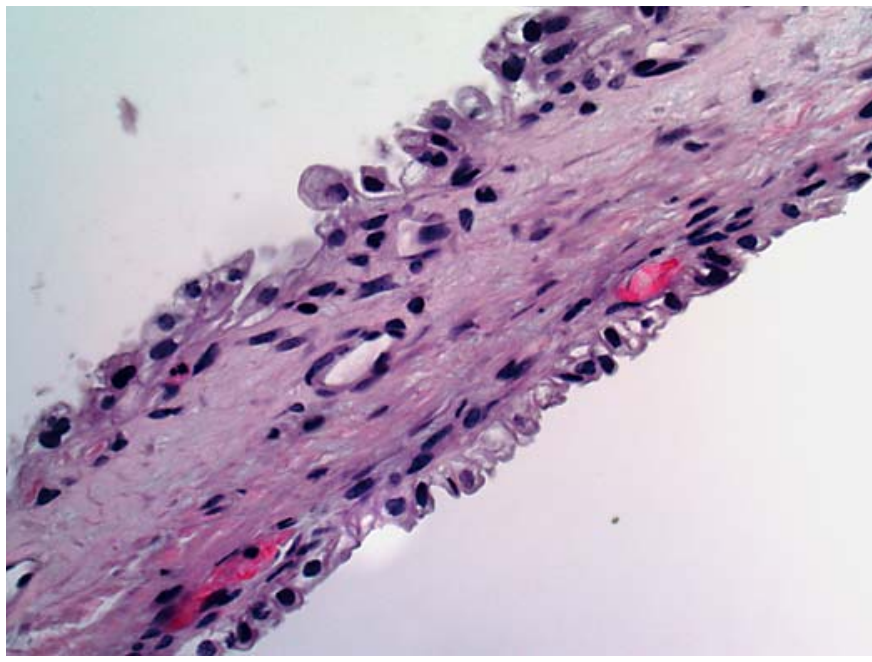

Fig. 4. High-power HE-stained image at $\times 40$ showing fibrous septa of the multilocular cystic lesion with epithelial cells lining either side showing prominent clearing of the cytoplasm and low-grade nuclei.

Clear cell RCC is the most common malignant tumor of renal epithelial origin in adults, accounting for more than $60 \%$ of all renal tumors. It has a highly malignant behavior. However, MCRCC, which is one of the clear cell subtypes of RCC, has an excellent prognosis and a low potential for metastasis. It comprises just $4 \%$ of all clear cell RCC [14]. Commonly, it is an incidental finding in up to $90 \%$ of the cases, and is usually a unilateral solitary lesion $[15,16]$. This type of clear cell RCC is found more in middle-age adults with a male-to-female ratio of 1.2-2.1:1 $[16,17]$.

MCRCC has a characteristic gross appearance, being a well-circumscribed mass composed exclusively of cysts of variable size. The tumor is separated from the kidney by a fibrous capsule, and the cysts are separated by thin septa [14]. Microscopic exam reveals cysts lined by a single layer of low-grade clear cells with abundant clear cytoplasm and small nuclei without nucleoli [14]. The septa consist of fibrous tissue containing clusters of tumor cells. These form small collections but not expansive nodules [18]. MCRCC has similar genetic abnormalities with clear cell RCC: chromosome 3p deletions (74\%) and von Hippel-Lindau mutations (25\%) [19, 20]. MCRCC can be differentiated from typical clear cell RCC by an absence of necrotic changes and large solid areas of tumor cells [21]. Immunohistochemical features are frequently characterized by diffusely positive cytokeratin 7 and less frequently by positive CD10 [22]. 
Table 1. Two previously reported cases with known pre-kidney transplant clear cell RCC and MCRCC undergoing kidney transplantation without RCC in recipients and our case

\begin{tabular}{|c|c|c|c|c|c|c|c|}
\hline Reference & $\begin{array}{l}\text { Age at RCC } \\
\text { diagnosis/ } \\
\text { race/gender }\end{array}$ & $\begin{array}{l}\text { Causes of ESRD/RRT } \\
\text { (years before kidney } \\
\text { transplantation) }\end{array}$ & Tumor characteristics & Treatment for tumors & $\begin{array}{l}\text { Tumor-free } \\
\text { waiting period }\end{array}$ & $\begin{array}{l}\text { Type of kidney } \\
\text { transplantation/ } \\
\text { immunosuppressive } \\
\text { medications }\end{array}$ & $\begin{array}{l}\text { Outcome after kidney } \\
\text { transplantation }\end{array}$ \\
\hline $\begin{array}{l}\text { Joshi et al } \\
\text { [32] }\end{array}$ & $1.37 / \mathrm{NA} / \mathrm{M}$ & $\begin{array}{l}\text { undetermined } \\
\text { (?long-standing DM } \\
\text { and prolonged use } \\
\text { of NSAID)/ } \\
\text { maintenance HD } \\
\text { (<1 year) }\end{array}$ & $\begin{array}{l}\text { an } 8 \times 7 \mathrm{~cm} \text { clear cell } \\
\text { RCC, grade } 1 \text {, } \\
\text { T2N0M0 at lower and } \\
\text { middle third of the } \\
\text { right kidney; } \\
\text { subsequently TCC } \\
\text { (pT1G2) }\end{array}$ & $\begin{array}{l}\text { right radical } \\
\text { nephrectomy; } \\
\text { subsequently TURBT } \\
\text { with adjuvant } \\
\text { intravesical BCG } \\
\text { immunotherapy }\end{array}$ & $\begin{array}{l}10 \text { and } 4 \text { years } \\
\text { after right } \\
\text { radical } \\
\text { nephrectomy } \\
\text { and TURBT, } \\
\text { respectively }\end{array}$ & $\begin{array}{l}\text { LRRT/predniso- } \\
\text { lone, azathio- } \\
\text { prine and cyclo- } \\
\text { sporine }\end{array}$ & $\begin{array}{l}\text { no tumor } \\
\text { recurrence after } \\
9 \text {-year follow-up } \\
\text { (19 years after } \\
\text { right radical } \\
\text { nephrectomy) }\end{array}$ \\
\hline
\end{tabular}

$\mathrm{AA}=$ African American; DDRT = deceased donor renal transplantation; LRRT = living-related renal transplantation; NA = not available; N/A = not applicable; RRT $=$ renal replacement therapy; TCC $=$ transitional cell carcinoma; TURBT $=$ transurethral resection of bladder tumor.

The tumor grade of RCC correlates with prognosis, and Fuhrman nuclear grades are widely used [23]. The majority of MCRCC are Fuhrman grade 1 [24]. There is no reported case of MCRCC with Fuhrman grade 4. The tumor node metastasis staging system is used to assess the disease for extension and is another important prognostic factor. Based on 5 series that included 94 patients with MCRCC ( 2 series used less than a strict 2004 WHO criteria for diagnosis of MCRCC), there were no reported cases of tumor metastasis or recurrence with a mean followup of 5.5 years [24-28]. In addition, MCRCC is one of the most benign subtypes of RCC which can be cured by surgical resection [24]. Patients with RCC with low grade, low stage, and $\leq 4 \mathrm{~cm}$ in diameter treated with nephronsparing surgery had similar outcomes in terms of progression-free, crude or cancer-specific survival to those treated with radical nephrectomy [29]. The mean diameter of MCRCC from the 5 series mentioned above was $4.57 \mathrm{~cm}$ [24-28]. Therefore, most MCRCC can be treated with nephron-sparing nephrectomy [30].

Overall, the favorable prognosis of MCRCC stems from its low Fuhrman nuclear grade and stage at diagnosis. This includes the small volume of tumor with the mean tumor size of $<5 \mathrm{~cm}$, and the diploid status on flow cytometry [24, 27]. Because of its benign nature, MCRCC was recently renamed as 'multilocular cystic renal cell neoplasm of low malignant potential' [20].

After being controlled or treated, different cancers require differing tumor-free waiting periods before the patients are eligible for kidney transplantation. Tumor-free waiting periods for RCC vary from no waiting time for incidentally found small $(<5 \mathrm{~cm})$ tumors and up to 5 years for large $(\geq 5 \mathrm{~cm})$ or invasive tumors [8]. However, MCRCC may not require any waiting time as long as it is completely resected. In one case, a newly diagnosed MCRCC at the time of living-related donor nephrectomy was not transmitted to the recipient even 10 years after kidney transplantation (table 1) [30].

The recurrence of RCC in post-kidney transplant recipients is concerning. Pathogenesis of malignancy in posttransplant recipients is (1) de novo occurrence in the recipient, (2) recurrent malignancy in the recipient and (3) transmission of malignancy from the donor [31]. In one reported case of known clear cell RCC, the patient successfully underwent living-related renal transplantation 10 years after a right radical nephrectomy. There was 
no evidence of tumor recurrence 9 years after kidney transplantation (table 1) [32]. However, in kidney transplant recipients, the prevalence of RCC in native kidneys was $1.25-3.9 \%$ (up to 100 times greater risk than general population) $[33,34]$ of and de novo RCC in renal grafts it was $0.25-0.5 \%[33,35]$. Therefore, routine screening renal ultrasonography or other imaging modalities even in asymptomatic post-kidney transplant recipients is strongly recommended in order to detect early small RCC in both native kidneys and renal grafts and to allow possible conservative management by nephron-sparing surgery $[34,35]$.

There is no consensus regarding the best diagnostic imaging for screening for RCC in kidney transplant recipients. Some studies showed a higher sensitivity to detecting RCC by MRI than by ultrasound ( 6 vs. $2 \%$ ). This is especially important in acquired cystic kidney disease, which is an underlying risk factor of RCC in ESRD [11]. However, MRI is not superior to renal ultrasound for detecting solid renal masses [9].

The onset of tumor occurrence in our patient is unclear. Like our patient, most MCRCC are incidentally found from radiological workup for other reasons, and the majority of the patients with MCRCC are asymptomatic. However, a higher hemoglobin level as found in our patient versus the usual level for ESRD patients, may suggest a high erythropoietin state from RCC.

Because we lacked previous imaging studies at the time of kidney biopsy, we cannot confidently identify evidence of tumor progression in our patient. One retrospective study showed that around one third of cystic RCC had an average increase in size of $10.5 \mathrm{~mm}$ during 6 months of follow-up and the remaining tumors did not significantly increase in size [36]. Our patient had a kidney biopsy around 1.5 years before undergoing left radical nephrectomy, and the pathology revealed MCRCC measuring $3 \mathrm{~cm}$ in greatest diameter. If we assume that the imaging at the time of kidney biopsy did not reveal any renal lesion, the rate of tumor growth in our patient would be approximately $1 \mathrm{~cm}$ in 6 months or $3 \mathrm{~cm}$ in 1.5 years. This is the same rate as seen in the above study. Our patient likely had MCRCC more than 1.5 years but no evidence of local invasion or distant metastasis. This is consistent with the benign nature of this cancer. Given the clear surgical margins, a decision to wait after radical nephrectomy before the patient would be eligible for kidney transplantation seems unnecessary.

There is an unclear relationship between RCC in renal transplant recipients and prior immunosuppressive medications. Type of induction immunosuppressive therapy

showed no difference in the incidence of de novo malignancies; however, conversion to mammalian target of rapamycin inhibitors as maintenance immunosuppression reduced the incidence of malignancies compared to calcineurin inhibitors $[37,38]$. Further studies are needed to address the recommended immunosuppressive medications for kidney transplant recipients with RCC.

\section{Conclusion}

Our case illustrates the effect of malignancy on prekidney transplant evaluation and tumor-free waiting periods. MCRCC is a malignancy with benign nature and may not need a tumor-free waiting period. This could lead to an increase in the eligibility of kidney transplant recipients or even donors with MCRCC. However, close follow-up in the post-kidney transplant period is required as immunosuppressive medications may potentially cause recurrent malignancy or de novo occurrence in these recipients.

\section{Acknowledgements}

The authors greatly appreciate Dr. Brian Weber from the Emory Department of Radiology and Imaging Sciences for the radiographic images and his comments, Dr. Natthaporn Tanpowpong from the Department of Radiology, Faculty of Medicine, Chulalongkorn University, Bangkok, Thailand, for her feedback, and the Department of Pathology and Laboratory Medicine, Emory University School of Medicine, for histopathology images.

\section{Disclosure Statement}

No financial support of any kind was received.

References

Am J Nephrol 2014;40:151-156 DOI: $10.1159 / 000365201$
No Tumor-Free Waiting Time:

Multilocular Cystic RCC
1 Suthanthiran M, Strom TB: Renal transplantation. N Engl J Med 1994;331:365-376.

2 Maisonneuve P, Agodoa L, Gellert R, et al: Cancer in patients on dialysis for end-stage renal disease: an international collaborative study. Lancet 1999;354:93-99.

- 3 Kauffman HM, Cherikh WS, McBride MA, et al: Post-transplant de novo malignancies in renal transplant recipients: the past and present. Transpl Int 2006;19:607-620.

4 Neuzillet Y, Tillou X, Mathieu R, et al: Renal cell carcinoma (RCC) in patients with endstage renal disease exhibits many favourable clinical, pathologic, and outcome features compared with RCC in the general population. Eur Urol 2011;60:366-373. 
$\checkmark 5$ Denton MD, Magee CC, Ovuworie C, et al: Prevalence of renal cell carcinoma in patients with ESRD pre-transplantation: a pathologic analysis. Kidney Int 2002;61:2201-2209.

-6 Gulanikar AC, Daily PP, Kilambi NK, et al: Prospective pretransplant ultrasound screening in 206 patients for acquired renal cysts and renal cell carcinoma. Transplantation 1998;66:1669-1672.

-7 Tickoo SK, dePeralta-Venturina MN, Harik LR, et al: Spectrum of epithelial neoplasms in end-stage renal disease: an experience from 66 tumor-bearing kidneys with emphasis on histologic patterns distinct from those in sporadic adult renal neoplasia. Am J Surg Pathol 2006;30:141-153.

-8 Kasiske BL, Cangro CB, Hariharan S, et al: The evaluation of renal transplantation candidates: clinical practice guidelines. Am J Transplant 2001;1(suppl 2):3-95.

$\checkmark 9$ Ljungberg B: Prognostic factors in renal cell carcinoma. Scand J Surg 2004;93:118-125.

10 Israel GM, Bosniak MA: Pitfalls in renal mass evaluation and how to avoid them. Radiographics 2008;28:1325-1338.

11 Muhlfeld AS, Lange C, Kroll G, et al: Pilot study of non-contrast-enhanced MRI vs. ultrasound in renal transplant recipients with acquired cystic kidney disease: a prospective intra-individual comparison. Clin Transplant 2013;27:E694-E701.

12 Israel GM, Bosniak MA: An update of the Bosniak renal cyst classification system. Urology 2005;66:484-488.

13 Putra LG, Minor TX, Bolton DM, et al: Improved assessment of renal lesions in pregnancy with magnetic resonance imaging Urology 2009;74:535-539.

14 Montironi R, Mazzucchelli R, Scarpelli M, et al: Update on selected renal cell tumors with clear cell features. With emphasis on multilocular cystic clear cell renal cell carcinoma. Histol Histopathol 2013;28:1555-1566.

15 von Teichman A, Comperat E, Behnke S, et al: VHL mutations and dysregulation of pVHLand PTEN-controlled pathways in multilocular cystic renal cell carcinoma. Mod Pathol 2011;24:571-578.
16 You D, Shim M, Jeong IG, et al: Multilocular cystic renal cell carcinoma: clinicopathological features and preoperative prediction using multiphase computed tomography. BJU Int 2011;108:1444-1449.

17 Moch H: Cystic renal tumors: new entities and novel concepts. Adv Anat Pathol 2011;17: 209-214.

18 Castillo OA, Boyle ET Jr, Kramer SA: Multilocular cysts of kidney. A study of 29 patients and review of literature. Urology 1991;37: 156-162.

19 Halat S, Eble JN, Grignon DJ, et al: Multilocular cystic renal cell carcinoma is a subtype of clear cell renal cell carcinoma. Mod Pathol 2010;23:931-936.

20 Srigley JR, Delahunt B, Eble JN, et al: The international society of urological pathology (ISUP) Vancouver classification of renal neoplasia. Am J Surg Pathol 2013;37:1469-1489.

21 Crumley SM, Divatia M, Truong L, et al: Renal cell carcinoma: evolving and emerging subtypes. World J Clin Cases 2013;1:262-275.

22 Williamson SR, Halat S, Eble JN, et al: Multilocular cystic renal cell carcinoma: similarities and differences in immunoprofile compared with clear cell renal cell carcinoma. Am J Surg Pathol 2012;36:1425-1433.

23 Fuhrman SA, Lasky LC, Limas C: Prognostic significance of morphologic parameters in re nal cell carcinoma. Am J Surg Pathol 1982;6: 655-663.

24 Suzigan S, Lopez-Beltran A, Montironi R, et al: Multilocular cystic renal cell carcinoma: a report of 45 cases of a kidney tumor of low malignant potential. Am J Clin Pathol 2006; 125:217-222.

25 Corica FA, Iczkowski KA, Cheng L, et al: Cystic renal cell carcinoma is cured by resection: a study of 24 cases with long-term followup. J Urol 1999;161:408-411.

26 Nassir A, Jollimore J, Gupta R, et al: Multilocular cystic renal cell carcinoma: a series of 12 cases and review of the literature. Urology 2002;60:421-427.

27 Murad T, Komaiko W, Oyasu R, et al: Multilocular cystic renal cell carcinoma. Am J Clin Pathol 1991;95:633-637.
28 Brinker DA, Amin MB, de Peralta-Venturina $\mathrm{M}$, et al: Extensively necrotic cystic renal cell carcinoma: a clinicopathologic study with comparison to other cystic and necrotic renal cancers. Am J Surg Pathol 2000;24:988-995.

29 Lerner SE, Hawkins CA, Blute ML, et al: Disease outcome in patients with low stage renal cell carcinoma treated with nephron sparing or radical surgery 1996. J Urol 2002;167:884889; discussion 889-890.

30 Weiss SG 2nd, Hafez RG, Uehling DT: Multiocular cystic renal cell carcinoma: implications for nephron sparing surgery. Urology 1998;51:635-637.

31 Morath C, Mueller M, Goldschmidt H, et al: Malignancy in renal transplantation. J Am Soc Nephrol 2004;15:1582-1588.

32 Joshi R, Mammen K, Pawar B: Successful renal transplantation after two separate urinary tract malignancies. Indian J Urol 2008;24: 256-257.

33 Tsaur I, Obermuller N, Jonas D, et al: De novo renal cell carcinoma of native and graft kidneys in renal transplant recipients. BJU Int 2011;108:229-234.

34 Doublet JD, Peraldi MN, Gattegno B, et al: Renal cell carcinoma of native kidneys: prospective study of 129 renal transplant patients. J Urol 1997;158:42-44.

35 Ploussard G, Chambade D, Meria P, et al: Biopsy-confirmed de novo renal cell carcinoma (RCC) in renal grafts: a single-centre management experience in a 2396 recipient cohort. BJU Int 2012;109:195-199.

36 Jhaveri K, Gupta P, Elmi A, et al: Cystic renal cell carcinomas: do they grow, metastasize, or recur? AJR Am J Roentgenol 2013;201:W292W296.

37 Opelz G, Henderson R: Incidence of nonHodgkin lymphoma in kidney and heart transplant recipients. Lancet 1993;342:15141516.

38 Schena FP, Pascoe MD, Alberu J, et al: Conversion from calcineurin inhibitors to sirolimus maintenance therapy in renal allograft recipients: 24-month efficacy and safety results from the convert trial. Transplantation 2009;87:233-242. 